\title{
WAR NOVEL: THE HISTORY OF DEVELOPMENT AND TYPOLOGY OF THE GENRE
}

\author{
Hrosevych Taras \\ Candidate of Philological Sciences, \\ Associate Professor of Cyclic Commission of Journalism, \\ ORCID ID 0000-0003-1503-0256 \\ Ivano-Frankivsk Branch of University "Ukraine", \\ Naberezhna Street named after V. Stefanyk, 42-A, Ivano-Frankivsk, 76010, Ukraine \\ grostar@ukr.net
}

The general regularities and main tendencies of the development of a war novel have been researched in the article, an attempt of its typology and periodization is realized, the most common genre models is identified.

The novel about the Second World War as a leading epic genre, which develops the theme of war in literature, creatively synthesized all the experience gained by the writers and front-line soldiers, became a noticeable artistic phenomenon and widespread genre formation in Western European, American and Slavic writing. It is concluded that the aesthetic and ideological-thematic level of artistic modeling of war reality is localized in different national literatures unevenly and stipulated first of all for the historical and geopolitical scope of the involvement of warring countries in hostilities. For example, in German military romance, is the so-called "Remarkable" novel, as well as a novel with a marked anti-militaristic nature. The main plot of the French war novel is the resistance movement, while the Italian one is fascist domination and occupation actions in the Balkans. Instead, in Britain, which has escaped occupation, military creativity takes a rather modest place. American writing focuses on war as a social phenomenon, armed conflicts in Vietnam.

The polivector artistic search, the richness of types and varieties of war novel (panoramic novel, lyric war novel, anti-fascist novel, soldier novel, war novel-education, war novel with documentary basis, etc.) demonstrates military novel prose of Eastern Slavs. In particular, in the development of the Ukrainian war novel, literary critics distinguish such branches as the war novel, the post-war novel of the first decade, the war novel prose of the "second wave" (etc. pol. 50's - 60's), war novel 70's-80's, as well as modern war novels.

Keywords: novel, war novel, genre, genre variety, genre model.

\section{ВОСННИЙ РОМАН: ІСТОРІЯ РОЗВИТКУ Й ТИПОЛОГІЯ ЖАНРУ}

\section{Гросевич Тарас}

Кандидат філологічних наук, доцент циклової комісії журналістики ORCID ID 0000-0003-1503-0256 Івано-Франківська філія Університету «Україна» вул. Набережна ім. В. Стефаника, 42-А, м. Івано-Франківськ, 76010, Україна grostar@ukr.net

У статті досліджуються загальні закономірності й основні тенденції розвитку воєнного роману, здійснено спробу його типології та періодизаиії, виокремлено найбільш поширені жанрові моделі.

Роман про Другу світову війну як провідний епічний жанр, щзо розвиває тему

(C) Hrosevych T., 2020 
війни в літературі, синтезував увесь набутий письменниками-фронтовиками творчий досвід, став помітним художнім явищем і розповсюдженою змістоформою в західноєвропейському, американському та слов'янському письменстві. Дійдено висновку, щзо естетичний та ідейно-тематичний рівень художнього моделювання воєнної дійсності локалізований у різних національних літературах нерівномірно та зумовлений передусім історичними ц̆ геополітичними масштабами залучення воюючих краӥн у воєнні дії. До прикладу, в німецькій воєнній романістиці розповсюдженим є т.зв. "ремаркистський» роман, а також роман з вираженим антимілітаристським характером. Натомість в Англії, яка уникла окупації, аналізований жанр займає скромне місие. Головним сюжетом франиузького воєнного роману виступає рух Опору, а італійського - фашистське панування й окупачійні дї на Балканах. Американські романісти сфокусовані на війні як соціальному явищі, збройних конфліктах у В'єтнамі.

Полівекторність художніх пошуків, багатство типів $i$ різновидів воєнного роману (панорамний роман, ліричний воєнний роман, антифашистський роман, солдатський роман, воєнний роман-виховання, воєнний роман з документальною основою та ін.) демонструє воєнна романна творчість східних слов'ян. Зокрема, в розвитку украӥнського воєнного роману літературознавиі виокремлюють такі відгалуження, як власне воєнний роман, післявоєнний роман периого десятиліття, воєнна романна проза «другої хвилі» (др. пол. 50-х - 60-ті рр.), воєнний роман 70-80-х рр., а також сучасна воєнна романістика.

Ключові слова: роман, воєнний роман, жанр, жанровий різновид, жанрова модель.

Постановка проблеми. Друга світова війна - епохальне явище в історії XX століття, один із магістральних образів і сюжетів художньої літератури. Письменник і літературознавець Б. Леонов писав: «Розмова про воєнну літературу є в кінцевому підсумку розмова про літературу взагалі, яка завжди виховувала в людях любов до рідної землі, до рідного народу, а отже, формувала в людині патріота, громадянина, воїна-захисника Батьківщини» [17, с. 324]. У дні війни літератори «крокували поруч 3 героями своїх майбутніх творів гарячими фронтовими шляхами, хоробро билися 3 ворогом, а коли потрібно було - віддавали своє життя...» [12, с. 20], що, власне, і спонукає до активізації наукового вивчення предмета дослідження, обгрунтовує його актуальність.

Провідним епічним жанром, що на тлі зображення воєнної дійсності актуалізує тему війни в літературі, порушує центральну проблему війни та миру, розвиває концепцію людини на війні тощо, є воєнний роман - поняття хоч і «досить умовне», зате «правомірне» [24, с. 354]. 3 метою уникнення багатозначностей у його тлумаченні під «воєнним романом» розглядатиметься у межах цієї статті лише романістика, присвячена Другій світовій війні.

Загалом «історія воєнної прози виступає (...) у загальних дослідженнях переважно як історія воєнного роману» [7, с. 21]. Теоретичні та історико-літературні аспекти жанру вивчалися у західному (Уолтер Аллен, Пітер Дж. Джонс та ін.), російському (В. Архипов, С. Белза, Ю. Бондарєв, В. Борщуков, А. Бочаров, К. Горбунова, Л. Іванова, І. Кузьмічов, Б. Леонов, Г. Ломідзе, М. Пархоменко, П. Топер, О. Цурганова та ін.), українському (В. Агеєва, В. Дончик, О. Дяченко, О. Ковальчук, М. Левченко, Л. Новиченко, В. Положій, В. Фащенко та ін.) літературознавстві. Однак у практиці сучасних вітчизняних дослідників намітилася тенденція до ігнорування вивчення воєнної романістики, що спричинило винесення зазначеного масиву літератури на периферію об'єктивного наукового аналізу.

Наша мета - простежити головні тенденції та загальні закономірності розвитку воєнного роману, здійснити його типологію та періодизацію, а також виявити найбільш поширені моделі жанру. 
Виклад основного матеріалу. В західноєвропейській прозі естетичний та ідейнотематичний рівень художнього моделювання Другої світової війни локалізований у національних літературах нерівномірно й зумовлений, на наш погляд, насамперед історичними та геополітичними масштабами залучення воюючих країн у воєнні дії.

Серед значного масиву літератури, створеного про наймасштабніший збройний конфлікт XX ст., важливе місце посідають твори німецьких письменників, які часто звертаються «до катастрофічного для фашистської Німеччини останнього періоду війни» [24, с. 283], змальовуючи їі «як прокляття минулого» [24, с. 292]. Звідси жанр німецького воєнного роману нерідко має виражений антимілітаристський характер, як-от роман Генріха Белля «Де ти був, Адаме?», пронизаний «ненавистю до війни як жахливого, протиприродного безглуздя» [24, с. 289].

Помітним жанровим різновидом, що визрів у надрах німецької воєнної романістики та «прижився» в інших національних літературах, є «ремаркистський» роман, пов'язаний з творами «Три товариші», «Тріумфальна арка» та «На Західному фронті без перемін» Е.-М. Ремарка, які «вільно чи мимоволі співвідносилися 3 книгами про війну радянських письменників» [17, с. 194-195]. Так, В. Архипов зауважує, що пафос подолання трагізму смерті як прикметна ознака східнослов'янського воєнного роману «різко зіштовхує його 3 «ремаркистським» романом про втрачене покоління, романом приглушених соціальних інстинктів і порушених зв'язків із землею» [3, с. 281]. В такому романі, мовляв, описується смерть, вбивство, насильство тощо - явища воєнної дійсності, охоплені т. зв. «темою могили», яка по-різному варіюється у назвах багатьох творів про Другу світову війну: «Живі і мертві» К. Симонова, «Мертві сорому не мають» Г. Бакланова, «Мертвим не боляче» В. Бикова, «Надгробний плач» поляка Б. Чешко, «На життя і смерть» болгарина Д. Ангелова, «Смерть - моє ремесло» француза Р. Мерля, «Мертві залишаються молодими» німкені Анни Зегерс, «Голі і мертві» американця Н. Мейлера.

В Англії, яка уникла окупації, воєнна творчість займає порівняно скромне місце. За словами Уолтера Аллена, «Друга світова війна не породила в Англії власне «воєнної літератури», яку ми пам'ятаємо за 20-ми роками» [2, с. 185]. Розгром англійських військ під Дюнкером, захист Лондона від нальотів гітлерівської авіації, підготовка до опору, дії воєнно-морського флоту, «конвойна служба», бойові операції англійських збройних сил, воєнні дії в інших країнах - основний сюжетний матеріал для таких романів, як «Справа честі» та «Морський орел» Д. Олдріджа, «Почесний меч» Івліна Во.

У французькому письменстві, як і в літературі інших країн, що боролися проти гітлеризму, - Бельгії та Нідерландів, Данії й Норвегії, Польщі та Югославії, Болгарії та Чехословаччини, - магістральним сюжетом виступає рух Опору. В Італії, до того ж, актуалізується тема фашистського панування і окупаційних дій на Балканах, а також участі італійського корпусу у війні проти Радянського Союзу.

В центрі уваги американських прозаїків перебуває в основному не війна, а саме армія як певний соціальний інститут. Авторський погляд на події 1939-1945 рр. тут значною мірою визначався крізь призму «малих», «брудних» воєн, зокрема у В'єтнамі.

Одним із найбільших воєнних романістів не тільки США, а й усієї світової літератури, є Ернест Хемінгуей. Його ідеї, на думку Пітера Дж. Джонса, втілилися у творчості всіх наступних західних романістів, стали, по суті, фундаментом розвитку жанру воєнного роману. «Ця книга (роман «По кому подзвін» - Т.Г.) про антифашистську війну займає особливе місце і в творчості Хемінгуея, і у всій літературі Заходу» [24, с. 222], - резюмує П. Топер.

Отож, розмірковуючи над проблемами гуманізму i жорстокості, вибору та відповідальності, над гранично загостреними фронтовими обставинами, воєнні романісти Заходу по-своєму осмислювали вплив війни на психологію особистості і на стан суспільної свідомості в ході війни $[8$, с. 85-86]. Як наслідок, закономірності 
функціонування західного воєнного роману виявилися в дечому відмінними від слов'янських художніх пошуків у цьому жанрі.

Високу динаміку розвитку демонструє воєнна романістика східних слов’ян, яка на тлі тотального насаджування думки про участь у війні «единого народа» розглядалася у «спільному» культурно-історичному полі, в контексті соцреалістичної парадигми, крізь призму вульгарно-соціологічних жанрових схем і трафаретів, а тому національно диференціювалася лише 3 приставкою «радянський». Грунтом для її виникнення, за М. Кузнєцовим, слугував романний епос революції - романи «Голий рік» Б. Пільняка, «Залізний потік» О. Серафимовича, «Ходіння по муках» О. Толстого, «Біла гвардія» М. Булгакова, «Справа Артамонових» М. Горького. Характерною рисою цих текстів $\epsilon$ їх гуманістичний пафос і героїчний зміст, «без творів про революційну героїку не змогла б із такою інтенсивністю розвиватися різноманітна проза про Другу світову війну» [7, с. 36].

Ю. Бондарєв у розвитку воєнно-історичного роману (такий аналог пропонує дослідник) виокремлює такі етапи:

- «початковий eman» (40-ві pp. ХХ ст.). Романи цього періоду написані журналістами або визнаними літераторами, що служили в армії військовими кореспондентами газет. Твори демонстрували перше, а тому не завжди глибоке пізнання воєнної дійсності, характеризувалися гострою публіцистичністю, репортажністю, квапливістю розповіді. Документальне фіксування подій було найціннішою їх якістю;

- «nіслявоєнний час» (середина та кінець 50-х рр.). Свій творчий потенціал воєнні романісти зазначеної доби реалізували в книгах так званої «окопної» та «масштабної правди». Не заперечуючи кращих традицій воєнної прози, вони несли заряд жорстокого драматизму (іх можна було дефініціювати як «оптимістичні трагедії»), всієї важкості війни. Головними героями стали солдати й офіцери одного взводу, роти, батареї чи полку. Такий епос був дистанційований від будь-якої ілюстрації, в ньому відсутні дидактизм, розчулення, раціональна виваженість, підміна внутрішньої правди зовнішньою, а переважала сувора й героїчна солдатська правда;

- 60-ті роки як «закономірна віха розвитку воєнно-історичного роману» [5, c. 437], що синтезувала основні художні пошуки першого і другого етапів. Інтерес письменників головним чином звернений до документального узагальнення та осмислення історичного минулого, до вичерпного пізнання всієї панорами війни, реконструювання iї подій тощо. Порушується ряд магістральних тем: світові події 39-го року, війна з Фінляндією, договір з Німеччиною про ненапад, підготовка до війни та мобілізаційні дії, роль Генштабу, Ставки Верховного Головнокомандування, дипломатії й генералітету в цих подіях.

За принципом «зображення моральної активності героя» [7, с. 151] А. Бочаров класифікує воєнну прозу на кульмінаційну та безкульмінаційну. В першому випадку бій виступає як кульмінація характеру, а не сюжету (хоч інколи вони збігаються). Для одних героїв це високе піднесення, осяяння, напруга всіх сил, а також вияв тих рис, які накопичувалися та визрівали упродовж твору. По суті, героїзм є вищим проявом активності воїна. Інших - жах битви надломлює, спустошує, еруптуючи назовні єдину форму поведінки - інстинкт самозбереження. Та в обох випадках бій сприймається як серйозне моральне потрясіння, тому автор видобуває 3 нього максимум можливостей для дослідження характерів у критичній ситуації.

Безкульмінаційна проза тяжіє до описів численних боїв і битв, оскільки має на меті не вивчення індивідуально-психологічних особливостей, а зображення фактів масового героїзму, фронтового становища, дій великих армійських мас, і зазвичай пов'язана зі значною протяжністю подій у часі. Дослідження морального потрясіння під час бою не є для автора архіважливим і замінюється активністю героя.

Власне, за принципом динаміки розвитку характерів А. Бочаров виокремлює наступні жанрові підвиди воєнного роману: 
- «роман-подія» 3 надзвичайно обмеженим у часі сюжетом;

- «роман-доля», сфокусований на становленні людського характеру - як у горнилі тяжких випробувань зароджуються моральні якості воїна, визріває героїчне начало і т.д.;

- «роман-життєпис», в основі якого лежать факти біографії, безпосереднє життя героя, коли читачам уже відомі його воєнні подвиги;

- «воєнний виховний роман», присвячений темі збагачення, загартовування, очищення людських чеснот на війні, закладених сім'єю, середовищем, суспільством;

- «роман-роздум». Дія таких творів розгортається неквапливо, зі значною кількістю бесід, монологів і діалогів та необов'язкових для воєнного роману побутових замальовок, що, в підсумку, підпорядковано головній меті - вільним роздумам автора «про доблесті, про подвиги, про славу».

Літературознавець В. Борщуков пропонує таку жанрову диференціацію великої прози про війну:

- «епічного складу» панорамний роман 3 яскраво вираженим публіцистичним елементом (Г. Коновалов, К. Симонов, О. Чаковський);

- роман-роздум, в якому визначальним $є$ не опис, а тлумачення подій (роман В. Кожевнікова «Ополудні на сонячній стороні»);

- реалістичні твори з широким використанням народнопоетичних, фольклорних мотивів (роман А. Кешокова «Зламана підкова»);

- романи й повісті як «філософсько-аналітичні художні «дослідження» психології і моралі людини на війні» [6, с. 207] (В. Биков, Ю. Бондарєв);

- ліричні повісті (Б. Васильєв, В. Росляков, Л. Якименко);

- «героїко-романтичні сказання» [6, с. 207] (повісті О. Гончара, М. Стельмаха).

Розгалуженою є типологія воєнного роману, запропонована Л. Івановою. В еволюції жанру дослідниця простежує дві основні форми:

- «багатоплановий, багатогеройний роман епічного складу з багатошаровою композиційною структурою» [13, с. 89], з глибоким та історично достовірним осмисленням війни, духовних і моральних проблем епохи, «переплетінням декількох часових відрізків (пряме «зрощення» історії з сучасністю, ретроспекція в минуле героя, звернення до різних періодів війни)» [13, с. 199]. Такими в російській літературі $€$ романи про війну М. Шолохова, К. Симонова, Ю. Бондарєва, П. Проскуріна, в українській - О. Гончара та П. Загребельного, в білоруській А. Адамовича.

- «мікророман, побудований на гостроконфліктній ситуації, 3 напруженою драматизацією подій і проблем» [13, с. 89], що виріс переважно 3 повісті та характеризується ущільненістю оповіді. Яскравими зразками мікророману слугують «У списках не значився» Б. Васильєва, «В серпні сорок четвертого» В. Богомолова, «Нагрудний знак «OST» В. Сьоміна, «Хатинська повість» А. Адамовича.

Важливим жанротвірним чинником у воєнному романі є принцип історизму, «зумовлений діалектичною єдністю історичної правдивості в описі подій і художньої концептуальності твору» $[13$, с. 87]. 3 огляду на це Л. Іванова виділяє роман, у структурі якого сучасність виражається післявоєнним часом, і роман, в якому епоху відтворено з позицій сучасності.

Крім того, за принципом співвідношення в романному тексті документальності й художності дослідниця виокремлює роман, в якому документальний матеріал поєднано з художнім («найчастіше це роман з розгалуженими сюжетними ходами, 3 великим потоком соціально-історичних подій, з багатьма персонажами і складною композиційною структурою» [13, с. 47]), та роман з документальною основою («має, умовно кажучи, монографічну структуру, коли в центрі уваги письменника перебуває один або кілька героїв, які організовують сюжет твору» [13, с. 47]).

Істотні судження про воєнний роман знаходимо в І. Кузьмічова. На його думку, основна відмінність між довоєнним і повоєнним романом полягає у специфіці моделювання образу героя. Якщо «у романах 20-30 років композиційний центр 
утворює перехід героїв зі старого в новий якісний стан», то «в післявоєнні роки основною турботою романіста стає розкриття краси (...) людини у всьому багатстві й різноманітті її натури» [15, с. 199]. Змінюється і принцип зображення героя. «Якщо раніше значне місце займала біографія персонажа, історія його життя, то тепер герой тримає іспит на людяність» [15, с. 199]. Його випробовують правдою і неправдою, любов'ю і війною, готовністю до подвигу, ідейними й політичними переконаннями, різними благами, славою, службовим становищем, смертельною небезпекою і навіть смертю.

Загалом еволюція аналізованого жанру, як пише I. Кузьмічов, тотожна історичному розвиткові двох основних відгалужень: післявоєнного та сучасного воєнного роману. В межах останнього виникає ще й форма ліричного воєнного роману, структура якого має свою специфіку. «Традиційні батальні картини 3 їх гуркотом і шумом у ліричному воєнному романі відсуваються на задній план або навіть зникають зовсім. Основним сюжетотворчим елементом стає не війна, а образ оповідача, ліричний герой, від імені якого ведеться розповідь» [15, с. 189], наголошує дослідник.

Поширеною жанровою модифікацією воєнного роману також є панорамний роман, в якому історичний процес «перетворюється в основний предмет оповіді», а долі окремих героїв «стають епізодичними картинами в русі роману» [19, с. 216]. У таких творах відтворено широку картину дійсності Другої світової війни, закарбовано окремі сторони життя тилу й фронту, та водночас їм бракувало «епохально-значної художньої ідеї, значних характерів, заглиблення в складні протиріччя часу, органічної єдності хронікально-історичного й індивідуального» [22, с. 92], «міцної документальної та історичної основи» [15, с. 300]. Наприклад, уже згаданий І. Кузьмічов уважав, що автори панорамних романів 50-х років не зуміли підняти свої твори до рівня «Тихого Дону».

Типологічну подібність жанрової структури демонструє «об'ємний воєнноісторичний роман», якому притаманні наступні детермінанти: наближеність до хроніки, документальна й фактична основа, зображення відомих історичних діячів, охоплення війни в широких часопросторових координатах - від солдатського окопу до Ставки Верховного Головнокомандування [8, с. 206].

У дослідженні «Сучасний роман і особливості літератури другої половини XX ст.» [26] О. Цурганова обгрунтовує відмінність жанрової парадигми воєнного від «антифашистського роману»: першому властива «чіткість моральних критеріїв в оцінці особистості та діяльності людини», тоді як «в антифашистському романі нема фаталізації дуалізму добра і зла», а «загибель героїв сприймається як оптимістична трагедія, як перемога життя» [26, с. 17].

Дещо іншу дефініцію - «антивоєнний роман» - пропонує С. Белза. На переконання дослідника, специфіку цієї змістоформи увиразнює зображення жахіть війни, сміливе оголення ii трагізму й антилюдяності, що «досягається різними способами - від сцен, що межують з натуралізмом, до високої символіки» [4, с. 139]. Звідси й висновок, що «воєнний» роман - це завжди роман антивоєнний» [4, с. 139].

Конститутивним фактором, що зумовив видозміни воєнного роману в процесі його розвитку, С. Белза вважає «філософсько-етичні проблеми» [4, с. 140]. Відповідно до міри їх художньої репрезентації, літературознавець виокремлює романи про війну 3 домінуванням одного 3 начал: медидативного, ліричного чи драматичного.

Г. Ломідзе, аналізуючи роман Ю. Бондарєва «Гарячий сніг», оперує поняттям «солдатський роман». Науковець зауважує, що «принципи поділу радянського воєнного роману за ознаками посад i чину» на «солдатський», а отже, і на «офіцерський або генеральський», достатньо не обгрунтовані, позаяк «і генерали, і офіцери були солдатами (...) війни», а «деколи не існувало ніякої різниці між долею офіцера і солдата», оскільки «ці долі були взаємно переплетені і тісно пов'язані між 
собою» [18, с. 199]. Отже, визначення «солдатський роман» є дещо умовним i, як бачимо, потребує більш детального роз'яснення.

У жанровій структурі воєнного роману невід'ємною $є$ «частка політичних мотивів» [21, с. 63]: зображення глобальних масштабів епохальних подій, протистояння ідеологій, соціальних таборів і принципів міжнародної політики держав, звернення до хроніки життя напередодні й під час Другої світової війни, міждержавних контактів, діяльності західних спецслужб, історичного досвіду війни, iii уроків для націй і поколінь тощо. Ці та інші риси іноді сприяли ототожненню воєнного роману з політичним. Такої долі, до прикладу, зазнали романи Ю. Семенова, «Блокада» О. Чаковського, «І один у полі воїн» Ю. Дольд-Михайлика.

Національна своєрідність воєнного роману зумовила появу нової епічної форми в українській літературі, «на яку колись О. Довженко покладав великі надії, чекаючи від неї видатного твору про народ у війні» [25, с. 156]. Художнє слово стало дійовим чинником у боротьбі проти фашизму, адже вже мало чималий досвід у розробці теми збройної боротьби під час громадянської війни. Цей досвід українські письменники творчо використовували і в роки Другої світової війни [11, с. 28]. Так, у лавах діючої армії перебувала третина складу Спілки письменників України, серед яких О. Довженко, А. Малишко, А. Головко, М. Бажан, В. Собко, С. Скляренко, В. Сосюра, Л. Первомайський, М. Стельмах, Л. Дмитерко, П. Усенко, В. Козаченко, Г. Тютюнник, О. Гончар, А. Дімаров. Ось як про це згадує Семен Скляренко: «Вихор війни кидав письменника в зовсім несподівані місця... Леоніда Первомайського знали на всіх українських фронтах, і в Румунії, і в Югославії, і в Болгарії. Іван Гончаренко і Василь Кучер до останнього дня були в обложеній Одесі, а пізніше в Севастополі. Вадим Собко - учасник і ветеран битви за Кавказ. Іван Ле, Андрій Малишко і ще багато товаришів були свідками Сталінградської епопеї. Сава Голованівський увійшов з частинами Червоної Армії в Крим зі сходу, від Тамані. Іван Нехода побував на далекому Калінінському фронті. Анатолій Шиян - учасник рейду славетного партизанського генерала Ковпака» [23, с. 111].

Літературознавець В. Дончик «безсумнівні витоки романістики про війну» $[9$, c. 12] вбачає у малій прозі воєнного періоду, представленої збірками оповідань «Поєдинок» С. Голованівського, «Завод-фортеця» Я. Гримайла, «Кров кличе» О. Десняка, «У ворожому тилу» О. Донченка, «З фронтового блокнота» Івана Ле, «Оповідання про хоробрість» М. Трублаїні, «Розплата» А. Шияна.

Перші романи про війну з фашизмом з'являються в українській літературі в 1941 1945 роках і належать перу Я. Баша («На берегах Славути» - «вдале поєднання «виробничого» і «сімейного» романів 3 певним використанням шпигунськопригодницького елементу» [9, с. 11]), Л. Смілянського («Свшан-зілля» як «перший український воєнний «партизанський» роман» [9, с. 20]), В. Собка («Кров України»), Н. Рибака («Зброя 3 нами»). Ці прозові полотна відзначалися панорамністю та епічністю художнього відображення світу, що досягалося, однак, «лише багатоплановістю й багатогеройністю», без «широти узагальнень, глибини психологічних спостережень (...) великої художньої сили образів, справжнього драматизму...» [9, с. 19], і були мінімальними щодо інших, більш оперативних 3 точки зору реакції на воєнні події, так званих «окопних» жанрів: агітаційної поезії, солдатської пісні, фронтового репортажу, а також нарису, повісті, оповідання.

Активізація романного мислення відбувається у післявоєнне десятиліття, хоч «основним жанром, що визначив рух воєнної теми в українській художній прозі протягом декількох років, стає повість» [20, с. 121]: «Атестат зрілості» В. Козаченка, «Земля гуде» О. Гончара, «Дума про невмирущого» П. Загребельного, «Сдина» Ю. Збанацького та ін. Саме 3 повістевих форм виріс роман О. Гончара «Прапороносці», повість С. Чорнобривця «Визволення» започаткувала його трилогію «Визволена земля» [14, с. 14-15].

Романістика перших повоєнних років розвивалася переважно в руслі художньодокументальної, а також колективно-сімейної тематичної лінії. Водночас помітним $\epsilon$ 
прагнення вітчизняних письменників до створення «великих епічних полотен, присвячених воєнній темі», а сам «воєнний роман цього періоду за масштабністю охоплення подій, як у просторі, так і в часі, тяжіє до панорамного зображення» [16, c. 53]. Романні здобутки «першого мирного десятиріччя» [9, с. 21] - широкі багатопланові романи «Шлях зорі» В. Собка, «Прапороносці» О. Гончара, «Південний захід» Івана Ле та О. Левади, «Карборундовий камінь» О. Донченка, перший воєнний роман «психологічного гатунку» «Вони не пройшли» Ю. Смолича, повість 3 «романним» сюжетом «Атестат зрілості» В. Козаченка та ін. - збагачували тематику шляхом актуалізації проблеми війни та миру, виведення воєнних подій на міжнародні обрії, використання різноманітних підходів до осмислення воєнної дійсності - як широко панорамного, так і особистісно-психологічного.

Плідні лінії розвитку українського воєнного роману накреслюються на рубежі 50 60-х pp. ХX ст., коли відбувається «значне жанрове розмаїття, збагачення й ускладненість романних структур», спостерігаються «активні пошуки засобів оновлення традиційних форм» [1, с. 210$]$, а в 60-70-х роках художня топографія війни розпросторюється в найрізноманітніших напрямках: 3 новими подробицями зображуються великі битви, партизанські рейди, трудова героїка військового тилу, боротьба «бандерівців» у західних областях, подвиги підпільників і розвідників, всебічно збагачується типаж героя, сюжетно-фабульна побудова воєнного роману.

Розвиваючись у руслі домінуючих - реалістично-аналітичної та лірикоромантичної - стильових течій («Щодо лірико-химерної течії, то для виділення іiі в рамках воєнної прози немає підстав» [1, с. 209]), у тісному зв'язку з іншими родами і жанрами літератури, український воєнний роман збагачувався, зазнавав новацій і трансформацій, утворюючі нові жанрові модифікації. Серед них - ліро-епічний «роман-поема» («Чотири броди» М. Стельмаха), багатоплановий панорамний роман («Степ» О. Сизоненка), роман про окуповане українське село («Вир» Г. Тютюнника «один із кращих творів української літератури про село часів війни» [12, с. 177], «фреска окупаційного лихоліття» [27, с. 77] «Біль і гнів» А. Дімарова, «Місяць над майданом» Б. Харчука) та про робітничий клас на війні («Надія» Я. Баша), «роман людських доль» («Тополя на тому березі» С. Голованівського - твір про форсування німецько-фашистськими загарбниками Дніпрогесу), філософський воєннопатріотичний роман («Дикий мед» Л. Первомайського), роман «зв’язку часів» («Твоя зоря» О. Гончара, «Розгін» П. Загребельного, «У серця своя пам'ять» П. Гуріненка), що характеризується «ускладненою композицією, 3 перехрещенням, чергуванням, зіставленням віддалених часових площин, історичних планів» [1, с. 248], «об'ємний роман хронікального типу» (трилогія «Степ», «Була осінь», «Мета» О. Сизоненка), «присвячений здебільшого найважливішим, переломним моментам війни», який «спирався на значну документальну основу» [1, с. 214]. Роман Ю. Дольд-Михайлика «I один у полі воїн» акумулював детективні елементи, а дилогія «Свропа 45» та «Європа. Захід» П. Загребельного - ознаки рідкісного для тодішньої української прози «пригодницько-політично-памфлетного» [20, с. 124] жанру.

Отож, роман кінця 60-х - першої половини 70-х рр. синтезував кращі риси воєнної, засвідчив появу нової художньої якості. Він хоч і не відмовився від здобутків попередніх етапів, зокрема досягнень і прорахунків панорамного роману першого повоєнного десятиріччя, та вже виходив за рамки «одного взводу чи роти, батальйону чи батареї» [16, с. 218], в його поле зору «потрапляють і довоєнне життя героїв, і саме воєнне лихоліття, і післявоєнна доля персонажів» [16, с. 219].

Варто наголосити на існуючій у літературознавчому дискурсі типології українського воєнного роману. Так, в основі класифікації В. Фащенка лежить типізуюча форма: художня (грунтується на одному, зіпертому на реальних спостереженнях, началі) чи художньо-документальна (має два стильових і фабульних крила). Залежно від того, який вид типізуючої форми домінує у воєнному романі, літературознавець виокремлює два утворення: 
- багатогеройний документальний воєнний роман, для якого документ підгрунтя твору й невід'ємний складник композиції. Зразками такого жанрового різновиду слугують трилогія «Степ», «Була осінь» і «Мета» О. Сизоненка, роман «Багряна вежа» О. Мусієнка;

- традииійний воєнний роман, в якому авторський вимисел зіпертий на реальному грунті, а «в центрі не народ чи народи, а доля людей чи однісї людини» [25, с. 161]. До цієї категорії В. Фащенко зараховує романи «Чорні бушлати» В. Логвиненка, «Найвищий закон» Д. Міщенка, «Поле бою» В. Лисенка.

Однак найбільш повною вважаємо типологію, запропоновану В. Дончиком у монографії «Український радянський роман: Рух ідей i форм» [10], де літературознавець окреслив головні шляхи розвитку українського воєнного роману, а саме:

- нечисленна воєнна романна проза 1941-1945 рр. («Запорожці» П. Панча, «Зброя з нами» Н. Рибака, «Євшан-зілля» Л. Смілянського, «Кров України» В. Собка та ін.). Зумовлені індивідуальними причинами й особливостями часу, що значно мінімізували можливості повноцінного й багатогранного осмислення воєнної дійсності, романи зазначеного періоду не були позбавлені недоліків. По суті, вони розвивали досягнення довоєнної історико-революційної романістики, накреслювали окремі риси та шляхи розвитку романів про війну наступних періодів i, як «перші ластівки» в цьому жанровому відгалуженні, започаткували нову для українського письменства тему;

- велика проза про війну другої половини 40-х - початку 50-х рр., т.зв. «повоєнного десятиліття» («Дніпро горить» Д. Бедзика, «Карборундовий камінь» О. Донченка, «Прапороносці» О. Гончара, «Південний захід» Івана Ле та О. Левади, «Атестат зрілості» В. Козаченка, «Вони не пройшли» Ю. Смолича, «Далекий фронт» В. Собка, «Велика рідня» М. Стельмаха, «Жива вода» Ю. Яновського та ін.), що розгортає тему війни «вшир, за рахунок нових тематично проблемних аспектів, сюжетів і характерів», проте «значно менше вглиб, до розкриття людської психології, гострих драм і трагедій, повноти правди про народ і людину» [10, с. 159];

- воєнний роман «другої хвилі» (період хрущовської «відлиги» та 60-ті рр.) («Людина і зброя» О. Гончара, «День для прийдешнього» П. Загребельного, «Дикий мед» Л. Первомайського, «Дума про тебе» М. Стельмаха, «Вир» Г. Тютюнника та ін.) як досить розвинуте й вельми різноманітне явище за формами, стилем і композицією: розпросторюється художня топографія війни, письменники відмовляються від схематичного типу ворога i глибше вникають у зміст категорії особистої відповідальності;

- воєнний роман 70-80-x («Липовий цвіт сорок першого» Б. Бойка, «Циклон» О. Гончара, «Біль і гнів» А. Дімарова, «Земля під копитами» В. Дрозда, «Зелені млини» В. Земляка, «Жорстоке милосердя» Ю. Мушкетика, «Чотири броди» М. Стельмаха, «Хуртовина» А. Шияна та ін.) - це, головним чином, роман пам'яті, що апелює до духовних і моральних засад людини, яка пройшла горнило війни, й утверджує, так би мовити, «пам'ять подвигу» (В. Агеєва). Воєнна романістика вказаного періоду представлена, приміром, романом «зв’язку часів», соціальнопсихологічним та епічним багатоплановим (батальним) романом, сільським або сімейним варіантом воєнного роману, поетика яких акумулює найрізноманітніші стильові домінанти: конкретно-реалістичні, романтично-психологічні, символічні.

Підсумовуючи, В. Дончик зауважує: «Український воєнний роман в цілокупності своїй явище досить своєрідне і багатопланове, солідне, в ньому представлені численні типи й форми романних структур» [10, с. 392]. Вершинним явищем вітчизняної воєнної романістики, як «справжня і велика художня перемога» [9, с. 22], що проклала «нові шляхи у воєнній темі» $[10$, с. 18], є, на думку дослідника, роман О. Гончара «Прапороносці».

Висновки. Роман про Другу світову війну, який синтезував набутий письменниками «на лінії вогню» творчий досвід, незважаючи на нерівномірну 
локалізацію у конкретних національних літературах, став помітним художнім явищем i поширеним жанровим утворенням у західноєвропейському, американському та слов'янському письменстві XX ст. Наприклад, у німецькій воєнній романістиці розповсюдженим є т.зв. «ремаркистський» роман, а також роман 3 вираженим антимілітаристським характером. Натомість в Англії, яка уникла окупації, аналізований жанр займає порівняно скромне місце. Головним сюжетом французького воєнного роману виступає рух Опору, а італійського - фашистське панування й окупаційні дії на Балканах. Американські романісти сфокусовані на війні як соціальному явищі, збройних конфліктах у В’єтнамі.

Воєнна романна проза східних слов'ян, незважаючи на штучне інтегрування у «спільне» та «єдиноправильне» культурно-історичне поле, включення в контекст радянських жанрових концепцій, демонструє полівекторність художніх пошуків, багатство типів i різновидів воєнного роману, як-от панорамний роман, багатоплановий роман, ліричний воєнний роман, антифашистський роман, солдатський роман, воєнний роман-виховання, воєнний роман 3 документальною основою та інші.

Витоки української романістики про війну доречно вбачати у малій прозі воєнного періоду. В цей час з'являються і перші романні спроби про війну 3 фашизмом («На берегах Славути» Я. Баша, «Свшан-зілля» Л. Смілянського, «Кров України» В. Собка та ін.), що започаткували нову для вітчизняної літератури тему, накреслили шляхи становлення жанру. Загалом же в розвитку українського воєнного роману доцільно виокремити такі відгалуження: власне воєнний (періоду війни) роман, післявоєнний роман першого десятиліття, воєнна романна проза «другої хвилі» (др. пол. 50-х - 60-ті рр.), воєнний роман 70-80-х рр., а також сучасна воєнна романістика, яка ще чекає свого дослідника.

\section{СПИСОК ВИКОРИСТАНИХ ДЖЕРЕЛ}

1. Агеєва В. П. Пам'ять подвигу (Українська воєнна проза 60-80-х років) / АН УРСР. Ін-т літ. ім. Т. Г. Шевченка / В. П. Агеєва. - К.: Наук. думка, 1989. - 272 с.

2. Аллен У. Традиция и мечта / У. Аллен. - М.: «Прогресс», 1970. - 434 с.

3. Архипов В. А. Герой и его земля / В. А. Архипов // Молодая гвардия. - 1972. - № 1. - C. 281-282.

4. Бэлза С. «Не просто война, но и революция» (Философско-этическая проблематика современной прозы о войне в литературах социалистических стран) / С. Бэлза // Литература великого подвига (Великая Отечественная война в литературе). Вып. второй. Сост. В. Борщуков, Л. Иванова. - М.: «Худ. лит.», 1975. - C. 117-144.

5. Бондарев Ю. В. Тенденция развития военно-исторического романа / Ю. В. Бондарев // Бондарев Ю. В. Собрание починений в 4-х т. Т. 3. Горячий снег. Роман. Публицистика. - М.: «Молодая гвардия», 1974. - С. 431-448.

6. Борщуков В. Связь времен (Идейно-эстетические особенности современной прозы о войне и критика) / В. Борщуков // Литература великого подвига (Великая Отечественная война в литературе). Вып. второй / Сост. В. Борщуков, Л. Иванова. - М.: «Худ. лит.», 1975. - С. 188-224.

7. Бочаров А. Человек и война: Идеи социалистического гуманизма в послевоенной прозе о войне / А. Бочаров. - М.: «Сов. писатель», 1978. - 480 с.

8. Горбунова Е. Н. Юрий Бондарев: Очерк творчества / Е. Н. Горбунова. - М.: «Сов. писатель», 1981. - 352 с.

9. Дончик В. Г. На війні - проти війни (Людина і народ в українській прозі 19411945 років) / В. Г. Дончик // Радянське літературознавство. - 1983. - № 5. - С. 1024.

10. Дончик В. Г. Український радянський роман: Рух ідей і форм / В. Г. Дончик. - К.: Дніпро, 1987. - 429 с. 
11. Дяченко О. С. Воїни і літописці: Літ.-крит. нарис / О. С. Дяченко. - К.: Рад. письменник, 1982. - 203 с.

12. Дяченко О. С. Подвиг народу: Літературно-критичний нарис / О. Дяченко. - К.: Дніпро, 1984. - 248 с.

13. Иванова Л. В. Современная советская проза о Великой Отечественной войне / Л. В. Иванова. - М.: «Наука», 1979. - 200 с.

14. Ковальчук О. Г. Український повоєнний роман: Проблеми жанрового розвитку: Навч. посібник / О. Г. Ковальчук. - К.: Вища школа, 1992. - 174 с.

15. Кузьмичев И. К. Герой и народ / И. К. Кузьмичев. - М.: «Современник», 1973. $336 \mathrm{c}$.

16. Левченко М. Художній літопис вогненних років: Дослідження / М. Левченко. К.: «Дніпро», 1977. - 227 с.

17. Леонов Б. А. Утверждение: Героико-патриотическая тема в русской и советской литературе / Б. А. Леонов. - М.: Худ. лит., 1988. - 381 с.

18. Ломидзе Г. И. Нравственные истоки подвига: Советская литература и Великая Отечественная война / Г. И. Ломидзе. - М.: Сов. писатель, 1985. - 208 с.

19. Назаренко В. Наш многоплановый роман / В. Назаренко // Звезда. -1958 . - № 8 . - C. 215-230.

20. Новиченко Л. Н. Украинский советский роман / Л. Н. Новиченко // Новиченко Л. Н. Избранные работы. В 2-х т. Т. 2. - М.: Худ. лит., 1985. - С. 71-182.

21. Пархоменко М. Роман семидесятых / М. Пархоменко. - М.: Худ. лит., 1987. - 334 c.

22. Пашкевич Н. Е. На эпическом направлении: подвиг народа в белорусском романе / Н. Е. Пашкевич. - М.: Сов. писатель, 1969. - 326 с.

23. Скляренко С. Письменник в шинелі / С. Скляренко // Дніпро. - 1946. - № 5. - С. 111.

24. Топер П. М. Ради жизни на земле. Литература и война. Традиции. Решения. Герои / П. М. Топер. - М.: «Сов. писатель», 1975. - 568 с.

25. Фащенко В. Героїка подвигу: Сучасний український воєнний роман /

B. Фащенко // Вітчизна. - 1984. - № 10. - С. 155-163.

26. Цурганова Е. А. Современный роман и особенности литературы второй половины XX ст. / Е. А. Цурганова // Современный роман: Опыт исследования. - М.: Наука, 1990. - C. 3-24.

27. Штонь Г. М. Анатолій Дімаров: Літ. портрет / Г. М. Штонь. - К.: Рад. письменник, 1987. - 150 с.

\section{REFERENCES}

1. Aheeva V.P. Memory of the Feat (Ukrainian Military Prose 60's-80's) / Science Academy of USSR. Institute of Literature named after T.H. Shevchenko / V.P. Aheeva. - K.: Naukova dumka, 1989. - 272 p.

2. Allen U. Tradition and Desire / U. Allen. - M.: «Progress», 1970. - 434 p.

3. Arhypov V.A. The Hero and His Land / V.A. Arhypov // Molodaia hvardyia. - 1972. № 1. - P. 281-282.

4. Belza S. "Not Just War, but not Revolution" (The Philosophical and Ethical Issue of Modern Prose about the War in the Literature of Socialistic Countries) / S. Belza // Literature of Great Feat (The Great Patriotic War in Literature). Second Issue. Compiled by V. Borshchukov and L. Ivanova. - M.: «Khudozhestvennaia literatura», 1975. - P. 117-144.

5. Bondarev Y.V. Development Trend of a Military Historical Novel / Y.V. Bondarev // Bondarev Y.V. Collection of Services in 4 Volumes. Volume 3. Hot Snow. Novel. Journalism. - M.: «Molodaia hvardyia», 1974. - P. 431-448.

6. Borshchukov V. Connection of Times (The Ideological and Aesthetic Features of Modern Prose about the War and Criticism) / V. Borshchukov // Literature of Great Feat 
(The Great Patriotic War in Literature). Second Issue. Compiled by V. Borshchukov and L. Ivanova. - M.: «Khudozhestvennaia literatura», 1975. - P. 188-224.

7. Bocharov A. Man and War: The Ideas of Socialist Humanism in Post-War Prose about War / A. Bocharov A. - M.: «Sovetskyi pisatel», 1978. - 480 p.

8. Horbunova E.N. Yurii Bondarev: Essay of Creativity / E.N. Horbunova - M.: «Sovetskyi pisatel», 1981. - 352 p.

9. Donchyk V.H. In War - Against War (Man and People in Ukrainian Prose 1941-1945) / V.H. Donchyk // Radianske literaturoznavstvo. - 1983. - № 5. - P. 10-24.

10. Donchyk V.H. Ukrainian Soviet Novel: Motion of Ideas and Forms / V.H. Donchyk. K.: Dnipro, 1987. - 429 p.

11. Diachenko O.S. Warriors and Chronicles: Literary and Critical Essay / Diachenko. - K.: Radianskyi pysmennyk, 1982. - 203 p.

12. Diachenko O.S. A Feat of the People: Literary and Critical Essay / O. Diachenko. - K. Dnipro, 1984. - 248 p.

13. Ivanova L.V. Modern Soviet Prose about the Great Patriotic War / L.V. Ivanova. - M.: «Nauka», 1979. - 200 p.

14. Kovalchuk O.H. Ukrainian Post-War Novel: Problems of Genre Development: educational textbook / O.H. Kovalchuk. - K.: Vyshcha shkola, 1992. - 174 p.

15. Kuzmichev I.K. The Hero and People / I.K. Kuzmichev. - M.: «Sovremennik», 1973. $336 \mathrm{p}$.

16. Levchenko M. Artistic Chronicle of Fiery Years: The Study / M. Levchenko. - K.: «Dnipro», 1977. - $227 \mathrm{p}$.

17. Leonov B.A. Statement: Heroic and Patriotic Theme in Russian and Soviet Literature / B.A. Leonov. - M.: Khudozhestvennaia literatura, 1988. - 381 p.

18. Lomidze H.I. The Moral Origins of the Feat: Soviet Literature and the Great Patriotic War / H.I. Lomidze. - M.: Sovetskyi pisatel, 1985. - 208 p.

19. Nazarenko V. Our Multifaceted Novel / V. Nazarenko // Zvezda. - 1958. - № 8. - P. 215-230.

20. Novychenko L.N. Ukrainian Soviet Novel / L.N. Novychenko // Novychenko L.N. Selected Works. In 2 Volumes. Volume 2. - M.: Khudozhestvennaia literatura, 1985. P. 71-182.

21. Parkhomenko M. The Seventies Novel / M. Parkhomenko. - M.: Khudozhestvennaia literatura, 1987. - $334 \mathrm{p}$.

22. Pashkevych N.E. In the Epic Direction: the Feat of People in the Byelorussian Novel / N.E. Pashkevych. - M.: Sovetskyi pisatel, 1969. - 326 p.

23. Skliarenko S. Writer in Greatcoat / S. Skliarenko // Dnipro. - 1946. - № 5. - P. 111.

24. Toper P.M. For Life on Earth. Literature and War. Traditions. Decisions. Heroes / P.M. Toper. - M.: «Sovetskyi pisatel», 1975. -568 p.

25. Fashchenko V. Hiroic Spirit of the Feat: Modern Ukrainian Military Novel / V. Vashchenko // Vitchyzna. - 1984. - № 10. - P. 155-163.

26. Tsurhanova E.A. Modern Novel and Features of Literature of the Second Half of Twentieth Century / E.A. Tsurhanova // Modern Novel: Research Experience. - M.: Nauka, 1990. - P. 3-24.

27. Shton H.M. Anatolii Dimarov: Literary Portrait / H.M. Shton. - K.: Radianskyi pysmennyk, 1987. - $150 \mathrm{p}$.

Надійшла до редакиії 27 січня 2020 р. 